\title{
The Analysis of Sentences' Unity of Students' Compositions at Grade VI of Elementary Schools in Bali Province
}

\author{
Ida Bagus Putrayasa \\ Dewa Putu Ramendra \\ Ida Bagus Putra Manik Aryana \\ Ganesha University of Education
}

\begin{abstract}
In conveying their ideas in writing, students often found some difficulties in composing sentences. The sentences composed, are not clear in terms of the unity of ideas, so that the ideas conveyed could not be understood well. Based on this situation, the main purpose of this study was to describe sentence unity used in the composition of grade VI students in Bali Province. The data were collected through document recording method of 120 compositions, each consisting of 3 paragraphs. The collected data were analyzed through Burton-Roberts analysis model. The results showed that there are 1.035 sentences. Of all the sentences, 984 sentences were categorized to have clear unity of ideas and 51 sentences were not clear in unity of ideas. The sentences in which the unity of the idea was unclear caused by the absence of Subject $(S)$ and Predicate (P), only include adverbials; without $S$, or without $P$. Based on the results obtained, it was suggested to the students to keep on paying attention on sentence unity in writing essay for the effectiveness of the ideas delivered.
\end{abstract}

Keywords: sentence analysis, unity, composition

\section{Introduction}

In conveying ideas in writing, students often found some difficulties composing sentences. The sentences composed, were not clear in terms of the unity of ideas and structures, so that the ideas conveyed could not be well understood. Therefore, a sentence became very important to be understood and mastered when conveying ideas, both orally and in writing. A sentence is a sequence of words that make sense (Reyner, 2016; Collins \& Stabler, 2016; Robert-Burton, 1997). Another opinion revealed that a sentence is a relation between one word with another. These interrelationships form an understanding (Putrayasa, 2014a; 2014b; 2014c). Meanwhile, another expert revealed that phrase is a string of words which carries a full idea (Collin \& Stabler, 2016, Osborne, et.al, 2012). In the string of the words, there are ideas submitted, which are represented at least through subject and predicate elements (Batterink \& Neville, 2013). The elements of a sentence have a harmony between the formers, the harmony of the subject with the predicate, the harmony of the predicate with the object, the harmony of the predicate with the adverbs (Robert-Burton, 1997; Putrayasa, 2014a). In addition to the harmony, another aspect to be considered in the sentence is the type of sentence used, the unity of the sentence, and the sentence structure used in delivering ideas (Clifton \& Frevier, 2010; Putrayasa, 2014b). The harmony of sentence elements, sentence unity, and sentence structure were what needs to be understood and mastered when communicating.

However, words strings were often discovered without full comprehension, both used in oral communication and written communication. One of these written communications was in a student's composition. A composition is a combination of several interconnected sentences, containing ideas. The composition was used only as a mean to analyze the sentences made by the students in their essay. In composing, students employed word strings to deliver their ideas, but there are some that did not contain a complete idea (understanding). This incomplete idea was shown by the nonpresence of Subject and Predicate. This was what made the students' composition interesting to be analyzed from the aspect of sentence unity and structure. These aspects could refine the syntactic study in the students' essay. In his research on syntax, especially sentence study, Putrayasa (2008) revealed that the students still had some difficulties to determine a word function in a sentence structure, whether as subject, predicate, object, complement, or adverb in a sentence. There were several studies that discussed syntax, among others: Putrayasa (2008, 2010, 2014), Maimunah (2014), and Baryadi (2014). The studies that had been conducted did not discuss in detail matters relating to sentence unity and sentence structure. 
Putrayasa's research (2008) which was conducted in Singaraja City only studied the subjects and predicates in students' essay through qualitative and quantitative approach. In 2010, a research on syntactic studies was conducted again, but only studied the mastery of students in distinguishing elements of objects and complements. Maimunah's study (2014) only examined clauses in terms of functions, categories, and roles in the Surah AlQari'ah's translation. The study had not been comprehensive, had not touched on sentence unity and structure in the Surah Al-Qari'ah's translation. Meanwhile, a research conducted by Baryadi (2014) only discussed the sequences of clauses in subordinative compound sentences in Indonesian language studied from a syntactic perspective.

A fairly comprehensive research related with the study of syntax, especially sentence elements but done separately, also conducted by Putrayasa (2014). His research examined the different elements of objects and adverbial. The results showed that students' ability was still low (average: 5.75) in determining the elements of the sentences. This was due to the poor students' understanding on the concept of sentences, the concept of the elements that form sentences in terms of type, unity, and structure. This poor understanding was added by the lack of exercises on how to determine sentence elements. With such poor understanding and practice, this would have an impact on the low quality of the language (sentences) used in conveying ideas, both orally and in writing.

Based on the above description of the background, the making of a study and theory about syntax, especially regarding sentence unity and structure, seemed urgent to do. This study had a strategic position as a basis for further research development and could be practically used as a reference of knowledge in delivering ideas orally or in writing. According to the description of the research and statements of earlier scholars and researchers, the mastery of syntax (especially sentences) could be understood in at least two aspects of the study: sentence unity and sentence structure. However, the problem that is focused in research is how was the unity of the sentence in the essay of the sixth grade students of elementary school in Bali province?

\section{Method}

The design used in this research was descriptive qualitative design. The source of research data was the essays of grade VI students in the province of Bali. The sample determination used random area sampling technique, namely random to elementary school representing North Bali, South Bali, West Bali, and East Bali. Each of these areas was represented by Buleleng Regency representing North Bali, Tabanan representing South Bali, Jembrana representing West Bali, and Karangasem representing East Bali. From each district was be taken 3 elementary schools, each with good category, medium, and less. Of each elementary school was taken 10 students 'essays. Thus, a total of 12 elementary schools and 120 student essays were used as samples of year I as shown in the table below.

Table 2.1: School Samples and Students' Essays

\begin{tabular}{|l|l|l|l|}
\hline No. & District & $\begin{array}{l}\text { The Number of } \\
\text { Elementary } \\
\text { Schools }\end{array}$ & $\begin{array}{l}\text { The Number of } \\
\text { Students'Essays }\end{array}$ \\
\hline 1 & Buleleng & 3 & 10 \\
\hline 2 & Tabanan & 3 & 10 \\
\hline 3 & Jembrana & 3 & 10 \\
\hline 4 & Karangasem & 3 & 10 \\
\hline Total & 12 & 120 \\
\hline
\end{tabular}

The method used in collecting data was document recording method. The collected data were analyzed through Robert-Burton analysis model.

\section{Finding and Discussion}

The data studied came from the essays of grade VI students in Bali province. The total number of essays was 120, each of which consisted of 3 paragraphs. The total number of sentences was 1,035 . This whole sentence was examined from the aspect of sentence unity and structure, as shown in the description below.

\section{Sentence Unity in the Essays of Grade VI Elementary School Students in Bali Province}

Based on data analysis conducted, it was discovered sentence unity in the essay of grade VI elementary school students as shown in Table 3.1 below. 
Table 3.1: Sentences Unity in the Essays of Grade VI Elementary School Students in Bali Province

\begin{tabular}{|l|l|l|l|}
\hline No. & Sentence Unity & Frequency & Total \\
\hline 1 & With S and P & $\mathbf{9 8 4}$ & $\mathbf{9 8 4}$ \\
\hline 2 & Without S and P & $\mathbf{2 3}$ & $\mathbf{2 3}$ \\
\hline 3 & Without S (Only Containing P) & $\mathbf{1 8}$ & $\mathbf{1 8}$ \\
\hline 4 & Without P (Only Containing S) & $\mathbf{1 0}$ & $\mathbf{1 0}$ \\
\hline Total & & $\mathbf{1 . 0 3 5}$ \\
\hline
\end{tabular}

The above table showed that almost all data (984 sentences) fulfilled the elements of sentence unity, namely Subject and Predicate elements. There are 23 sentences that did not fulfil unity, i.e. did not contain S and P, 18 sentences without $\mathrm{S}$ or contained only $\mathrm{P}$, and 10 sentences without $\mathrm{P}$ or contained only S. Analyzing from the number of sentences that fulfilled the elements of unity, it showed that the students understand very well how to express idea so that the ideas conveyed can be well understood by the reader. Of course, the ideas conveyed through the sentences had to contain a complete idea. In order for the sentences conveyed contained a complete idea, there should be a subject and predicate. This was in accordance with the opinions of Robert-Burton (1997) and Nordquist, R. (2016) which revealed that a sentence must contain a subject and a predicate. With the existence of the subject and predicate in a sentence, then the sentences were easy to understand because it already contained complete ideas. This opinion was supported by the research results conducted Putrayasa $(2017 \mathrm{a}, \mathrm{b})$ which revealed that easily-understood sentences are the sentences that contain the elements Subject and Predicate. It is this Subject and Predicate elements that provide complete idea. Meanwhile, a string of words containing no subject and predicate elements, containing only element $\mathrm{S}$, and containing only $\mathrm{P}$ elements can be cited as shown in the data example below. (More data can be seen in the attachment).

1) does not contain element $S$ and $P$ :

- Pada hari libur kemarin. (Kr.1 / P1 / SD5.J).

2) does not contain $\mathrm{S}$ (contains only $\mathrm{P}$ ):

- Selalu membuat seluruh kurcaci tersenyum bahagia. (Kr.1 / P1 / SD6.J).

3) does not contain $\mathrm{P}$ (contains only $\mathrm{S}$ ):

- Pantai sanur dan pantai kuta. (Kr.10 / P2 / SD1.J).

The above examples are strings of words that do not contain a complete idea, since there are no $\mathrm{S}$ and $\mathrm{P}$ elements (in Example 1), no S element (in Example 2), and no P element (in example 3). The three strings of the words in the above examples are not sentences, because they do not contain a complete idea. In order for the word strings contains a complete idea, there should be $\mathrm{S}$ and $\mathrm{P}$ element in it. The existence of $\mathrm{S}$ and $\mathrm{P}$ elements make the word strings classified as sentence. This is consistent with the opinion (Reyner, 2016; Collins \& Stabler, 2016; and Clifton \& Frevier, 2010) stating that a sentence is a string of words that have complete idea. This complete idea is characterized by the presence of elements $\mathrm{S}$ and $\mathrm{P}$.

\section{Conclusions and Recommendations}

Based on the results and data analysis above, it could be concluded as follows. 1) The essays of grade VI of elementary school students in Bali Province pointed that: (a) almost all sentences (984 pieces) fulfilled sentence unity, namely Subject and Predicate elements; (b) there were 23 sentences that did not comply with the unity element, i.e. not containing S and P; (c) 18 sentences without S or containing only P; and (d) 10 sentences without $\mathrm{P}$ or containing only $\mathrm{S}$. Based on these conclusions, it could be recommended that the sentence unity in conveying ideas should be maintained so that communication, both orally and in writing, became effective.

\section{References}

Baryadi, P. (2014). Urutan Klausa dalam Kalimat Majemuk Subordinat Bahasa Indonesia: Kajian dari Perspektif Sintaksis dan Wacana. Jurnal Sintaksis Lanjut, Rabu 4 Juni 2014.

Batterink, L. \& Neville, H.J. (2013). The Human Brain Processes Syntax in the Absence of Concious Awareness. The Journal of Neuroscien, 8 May 2013, 33 (19): 8528-8533; doi:10, 1523/J/NEUROSCI.0618-13. 2013.

Bogdan, R.C. \& Biklen, S.K. 1990. Penelitian Kualitataif untuk Pendidikan. Jakarta: Pusat Antar Universitas.

Chomsky, N. (1985). Syntactic Structures. Paris: Mouton Publishers.

Clifton, C. \& Frazier, L. (2010). Imperfect Ellipsis: Antecedents beyond Syntax? Journal of Syntax. Vol.13, Issue 4, p 279-297, Des. 2010. Blackwell Publising LTd. 
Collin, C. \& Stabler, E. (2016). A Formalization of Minimalist Syntax. Journal of Syntax. Vol.19, Issue 1, p 43-78, March 2016. Blackwell Publising LTd.

Huddleston, R.D. \& Uren, O. (1981). Declarative, Interogative, and Imperative in French dalam M.A.K. Halliday dan J.R. Martin (Ed.). Reading in Systemic Linguistics: 237-256. London: Batsford Academic and Education Ltd.

Lincoln, Y.S. \& Guba, E.G. 1985. Naturalistic Inquiry. New Delhi: Sage Publication.

Lindlof, T. R. (1994). Qualitative Communication Research Methods. Thousand Oaks: SAGE Publiser.

Maimunah, S. (2014). Analisis Klausa Berdasarkan Fungsi, Kategori, dan Peran pada Terjemahan Surah Al-Qaria'ah Ayat 1-11. Jurnal Sintaksis Lanjut, Rabu 4 Juni 2014.

Nordquist, R. (2016). Grammar Basics: Sentences Parts and Sentences Structure. http://grammar.about.com/od/rs/fl/sentence-structure.htm.

Osborne, T. at.al. (2012). Catenae: Introducing a Novel Unit of Syntactic Analysis. Journal of Syntax. Vol.15, Issue4, p 354-396, Des. 2012. Blackwell Publising LTd.

Putrayasa, I.B. (2001). Penerapan Model Inkuiri dalam Pembelajaran Bahasa Indonesia (Unsur-unsur Kalimat Tunggal). Disertasi (Tidak diterbitkan).

Putrayasa, I.B. (2002). Penerapan Model Inkuiri dalam Pembelajaran Bahasa Indonesia Jurnal Pendidikan dan Pengajaran, No.2 Tahun XXXV April 2002.

Putrayasa, I.B. (2008). Tata Kalimat. Aksara, Jurnal Bahasa dan Sastra, No.32, Tahun XIX. Desember 2008. Balai Bahasa Denpasar.

Putrayasa, I.B. (2010). Penerapan Model Konstruktivisme Berpendekatan Inkuiri dalam Pembelajaran Bahasa Indonesia (Studi Penelusuran Miskonsepsi dalam Pembelajaran Kalimat). Jurnal Pendidikan dan Pengajaran Undiksha, Jilid 43, No.1, April 2010.

Putrayasa, I.B. (2011). Studi Penelusuran Miskonsepsi dalam Pembelajaran Sintaksis (Tata Kalimat) dengan Model Konstruktivisme Berpendekatan Inkuiri pada Siswa Kelas I SMPN di Kota Singaraja, Kabupaten Buleleng, Provinsi Bali. (Prosiding Konferensi Internasional Masyarakat Linguistik Indonesia KIMLI-, 2011).

Putrayasa, I.B. (2012). Jenis Kalimat dalam Bahasa Indonesia. Bandung: Refika Aditama.

Putrayasa, I.B. (2013). Penelusuran Miskonsepsi dalam Pembelajaran Tata Kalimat (Unsur Objek dan Pelengkap) dengan Pendekatan Konstruktivisme Berbasis Inkuiri. Jurnal Pendidikan Indonesia Volume 2, Nomor 2, Oktober 2013.

Putrayasa, I.B. (2014a). Tata Kalimat Bahasa Indonesia. Bandung: Refika Aditama.

Putrayasa, I.B. (2014b). Analisis Kalimat (Fungsi, Kategori, dan Peran). Bandung: Refika Aditama.

Putrayasa, I.B. (2014c). Kalimat Efektif (Diksi, Struktur, dan Logika). Bandung: Refika Aditama.

Putrayasa, I.B. (2015). Pembelajaran Bahasa Indonesia (Kalimat: Unsur Objek dan Adverbial) dengan Model Konstruktivisme Berpendekatan Inkuiri. (Prosiding Seminar Internasional, Malang, 28-29 September 2015).

Putrayasa, I.B. (2016). Kajian Pengajaran Bahasa dan Sastra Indonesia. Makalah Disampaikan dalam Seminar Nasional Bahasa, Sastra, dan Pengajarannya IV. Denpasar, 2016.

Putrayasa, I.B. (2017). Sintaksis (Memahami Kalimat Tunggal). Bandung: Refika Aditama.

Putrayasa, I.B. (2017). Penggunaan Kalimat pada Jurnal Ilmiah Pendidikan dan Pembelajaran Program Pascasarjana. (Laporan Penelitian). Singaraja: Universitas Pendidikan Ganesha.

Putrayasa, I.B. (2017a). The Semantic Study of Language Politics. International Journal of Linguistics, Language, and Culture (IJLLC). Vol.3, N0.2, March 2017, p.6-11

ISSN: 2455-8028, Imfact Factor: 4.665/Thomson Reuters: K-4288-2016.

Putrayasa, I.B. (2017b). Unity and Effectiveness of the Abstract Language Beginner Lecturer Research Institution (Undiksha) 2015. IOSR Journal of Humanities and Social Science (IOSR-JHSS). V01.22, Issue 3, Ver.V (March 2017), p.23-28, e-ISSN: 2279-0837, p-ISSN: 2279-0845

Reyner, K. (2016). The Interaction of Syntax and Semantic During Sentence Proccessing: Eye movements in the Analysis of Semantically Based Sentences. Departement of Psychology University of Massachussetts, Mass.01003. Published by Elsevier Inc.

Robert-Burton, N. 1997. Analysing Sentences. New York: Longman.

Tallerman, M. (2011). Understanding Syntax. London: Hodder Education.

Thornoboy, S. (2009). How to Teach Grammar. Edinburgh: Pearson Education Limited.

Vallin, R.D.V. \& LaPolla, R.J. (1997). Syntax: Structure, Meaning, and Fungtion. Cambridge: University Press. 